\title{
Unsur Budaya dalam Komunikasi Berbahasa Jepang di Dunia Korporasi di Indonesia: Kajian Konflik Interkultural
}

\author{
Cultural Elements in Japanese Language Communication \\ in the Corporate World in Indonesia: An Intercultural Conflict Study
}

\author{
Arianty Visiaty \\ Universitas Al Azhar Indonesia \\ ariantyvisiaty@uai.ac.id
}

\begin{abstract}
Language and culture are two things that are interrelated and cannot be separated. This study aims to determine the conflicts caused by language, which cause misunderstanding due to culture. This study also discusses the background of cultural values that creates this misunderstanding. This research is a qualitative research conducted by interviewing four graduates of the Japanese Language Study Program. The analysis results identified two types of conflict caused by language, namely, conflicts caused by verbal and nonverbal language. These conflicts occur because of the different cultural backgrounds.
\end{abstract}

Keywords: business Japanese, conflict, intercultural

\section{INTISARI}

Bahasa dan budaya adalah dua hal yang saling terkait dan tidak dapat dipisahkan. Tujuan penelitian ini adalah untuk mengetahui konflik-konflik yang disebabkan oleh bahasa yang menyebabkan kesalahpahaman akibat budaya. Penelitian ini juga membahas latar belakang nilai budaya yang menyebabkan kesalahpahaman tersebut. Penelitian ini merupakan penelitian kualitatif yang dilakukan dengan mewawancarai empat orang lulusan Program Studi Bahasa dan Kebudayaan Jepang. Hasil analisis mengeidentifikasi dua jenis konflik yang disebabkan oleh bahasa, yaitu konflik yang disebabkan oleh bahasa verbal dan nonverbal. Konflik-konflik ini terjadi karena latar belakang budaya yang berbeda.

Kata kunci: bahasa Jepang bisnis, konflik, interkultural 


\section{PENDAHULUAN}

Era globalisasi telah membuka peluang untuk bekerja di berbagai negara di dunia. Banyak orang asing yang bekerja di Indonesia dan banyak pula orang Indonesia yang bekerja di luar negeri. Termasuk tenaga kerja orang Indonesia yang bekerja di Jepang. Jepang, sebagai negara yang dalam kondisi krisis jumlah tenaga produktif, memerlukan tenaga asing untuk bekerja di perusahaan Jepang di Jepang. Sehingga pada saat ini Jepang membuka seluas-luasnya kesempatan bagi tenaga kerja asing yang mempunyai kemampuan untuk bekerja di Jepang. Hal ini sejalan dengan Memorandum of Cooperation on A Basic Framework for Proper Operation of the System Pertaining to Foreign Human Resources with the Status of Residence of Specified Skilled Workers (MoC SSW) yang ditandatangani oleh Pemerintah RI dan Pemerintah Jepang pada tanggal 25 Juni 2019. Parlemen Jepang mengesahkan amandemen Immigration Control and Refugee Recognition Act bulan Desember 2018 dengan menambah 2 kategori baru status visa bekerja yaitu Specified Skilled Worker (SSW). SSW tertuang di dalam MoC SSW antara pemerintah Indonesia dan Jepang, sehingga makin memperluas kesempatan pekerja Indonesia bekerja di Jepang.

Di lain sisi dalam rangka bersaing dengan ekonomi dunia, Jepang berusaha memperluas bisnis di luar negeri karena dapat menekan biaya produksi, termasuk di Indonesia. Sehingga banyak perusahaanperusahaan Jepang yang berkembang di Indonesia. Perusahaan-perusahaan tersebut mengirim wakilnya dari Jepang untuk mengelola dan mengawasi jalannya perusahaan. Menurut Badan Koordinasi Penanaman Modal, Jepang melaporkan realisasi investasi Jepang ke Indonesia 20142019 mencapai US\$ 25,2 miliar atau senilai Rp 365,4 triliun. Dengan akumulasi tersebut, dalam periode 2014-2019, investasi Jepang selalu bertengger di posisi kedua terbesar setelah Singapura.

Ekspatriat dari Jepang yang dikirim ke Indonesia harus bekerja sama dengan pekerja lokal orang Indonesia untuk menjalankan bisnisnya di Indonesia. Para ekspatriat ini kebanyakan tidak bisa berbahasa Indonesia dan kurang pengetahuan tentang budaya Indonesia. Lulusan program studi yang terkait bahasa Jepang, hampir sebagian besar bekerja di perusahaan Jepang. Kemampuan bahasa para lulusan ini diharapkan menjadi jembatan antara ekspatriat orang Jepang dengan pegawai orang Indonesia. Akan tetapi, pada kenyataannya sering terjadi konflik yang terjadi bukan hanya karena kemampuan bahasa yang kurang, namun juga disebabkan oleh kemampuan pemahaman budaya yang masih kurang pada orang Indonesia maupun Jepang. Bahasa dan budaya merupakan dua hal yang tidak dapat dipisahkan. Ketika seseorang berbahasa, selalu ada unsur budaya yang melatarinya. Hal ini yang menyebabkan ketika dua atau lebih orang yang mempunyai budaya yang berbeda berkomunikasi, rentan terjadi kesalahpahaman ataupun konflik.

Salah satu konfilk yang sering dihadapi oleh lulusan bahasa Jepang yang telah bekerja di perusahaan Jepang adalah karena penggunaan bahasa yang mengandung makna berbeda terkait unsur budaya yang 
berbeda antara orang Indonesia dan orang Jepang. Penelitian terdahulu terkait dengan dengan konflik dan masalah perbedaan budaya di perusahaan Jepang adalah penelitian Nishitani (2016). Nishitani (2016) berfokus pada kekhawatiran dan kegagalan pada komunikasi bisnis yang dialami oleh pekerja dari Jepang dan orang Vietnam yang bekerja di perusahaan Jepang di Vietnam. Pada penelitian ini, bahasa tidak menjadi persoalan pekerja, karena hanya satu orang yang menyatakan bermasalah dengan bahasa.

Penelitian lain tentang konflik telah dipaparkan pula oleh Sonoda (2014) yang meneliti tentang contoh konflik interkultural yang terjadi di dunia korporasi melalui dokumen. Penelitian ini dilakukan dengan metode konten analisis, dengan data buku umum, buku teks pelajaran, jurnal, tesis/disertasi, dan sebagainya yang mengandung contoh-contoh konflik. Hasil dari penelitian ini menyimpulkan bahwa ciriciri konflik dapat dilihat dari empat hal, yaitu situasi (cenderung terjadi di luar negeri), strategi yang digunakan untuk menyelesaikan konflik, strategi yang disukai, dan sebab terjadinya konflik tersebut.

Salah satu penyebab terjadinya konflik dan masalah adalah kurangnya kemampuan komunikasi interkultural. Komunikasi interkultural ini tidak lepas dari pengetahuan bahasa dan budaya. Kaitan bahasa dan budaya dengan komunikasi interkultural terlihat dalam penelitian Peltokorpi (2010) serta Harzing, Köster, dan Magner (2011). Kedua penelitian tersebut menyimpulkan bahwa kemampuan bahasa dan pemahaman nilai budaya mempengaruhi kelancaran komunikasi interkultural di perusahaan dan mempengaruhi pilihan strategi yang digunakan untuk kelancaran komunikasi.

Untuk mengurangi konflik di dunia bisnis seperti yang dijelaskan di atas, maka perlu adanya kajian tentang pembelajaran bahasa Jepang bisnis, termasuk pengembangan bahan ajar bahasa Jepang bisnis. Ada beberapa penelitian yang berfokus pada pengembangan buku ajar bahasa Jepang bisnis atau komunikasi bisnis bahasa Jepang, di antaranya penelitian Nishitani (2014) dan Kin (2009). Nishitani (2014) melakukan penelitian pengembangan bahan ajar komunikasi bahasa Jepang bisnis. Penelitian ini dilakukan dengan mewawancarai enam orang Jepang, dan sepuluh orang asing asal Myanmar dan Vietnam. Hasil analisis dari wawancara tersebut menunjukkan bahwa dalam komunikasi bisnis, sering terjadi masalah yang disebabkan karena ketidaksesuaian perintah orang Jepang dan apa yang dilakukan oleh pekerja asing. Berdasarkan hal ini, Nishitani (2014) mengusulkan metode pembelajaran yang bertujuan untuk memahami bagaimana orang Jepang memberi perintah atau petunjuk pekerjaan. Metode pembelajaran tersebut menekankan perlunya pengajar bahasa Jepang memberikan contoh kasus tugas yang diberikan atasan orang Jepang. Pembelajar kemudian memilih tindakan yang akan dilakukan, kemudian pengajar memberikan penjelasan mengenai ekspresi bahasa terkait tindakan yang akan dilakukan. Pengajar bahasa Jepang juga membahas petunjuk bekerja yang dilakukan orang Jepang dan menjelaskan nilai-nilai dan latar belakang budaya orang Jepang. 
Sedangkan Kin (2009) melakukan penelitian dengan menelaah sebelas buku bahasa Jepang bisnis yang beredar di pasaran. Penelitian tersebut berfokus pada tujuan buku ajar, target pembelajaran, struktur setiap bab, silabus yang digunakan, dan isi buku. Hasil analisisnya menyimpulkan bahwa dari sebelas buku bahasa Jepang bisnis tersebut, hanya tiga buku yang memperkenalkan materi budaya dan etika Jepang. Hal ini berarti buku yang memasukkan unsur budaya/ etika/norma maupun perbedaan budaya masih sedikit.

Penelitian Nishitani (2014) maupun Kin (2009) mempunyai tujuan akhir berupa pengembangan materi ajar yang sesuai dengan kebutuhan perusahaan. Berdasarkan kedua hasil penelitian tersebut dapat disimpulkan bahwa memasukkan unsur budaya ke dalam buku ajar merupakan hal yang sangat krusial. Akan tetapi, buku ajar yang beredar di masyarakat selama ini hanya sedikit yang mengandung materi budaya. Oleh karena itu, pengembangan buku ajar yang tidak hanya menekankan unsur bahasa, namun juga unsur budaya, perlu dilakukan.

Dari hasil-hasil penelitian di atas dapat disimpulkan bahwa konflik yang terjadi di dunia korporasi Jepang antara pekerja asing dan pekerja asal Jepang dapat disebabkan karena kurangnya pengetahuan bahasa dan budaya yang berkaitan erat satu sama lain. Sementara di dalam buku ajar bahasa Jepang bisnis, materi budaya masih sangat minim. Pembelajaran hanya berfokus pada bahasa bisnis saja, tidak terlalu menekankan aspek budaya. Budaya hanya dijelaskan secara sepintas lalu. Hal ini yang menyebabkan terjadinya konflik atau masalah antara lulusan bahasa Jepang dengan ekspatriat asal Jepang ketika mereka bekerja di perusahaan Jepang. Konflik ini tidak hanya konflik yang terkait dengan perbedaan budaya secara umum saja, tetapi karena bahasa yang digunakan pun mengandung makna budaya yang berbeda.

Dalam rangka pengembangan materi ajar komunikasi bisnis Jepang, materi budaya yang terkait bahasa perlu untuk dimasukkan. Bahasa di sini bisa berupa kata, frasa atau ungkapan yang sarat unsur budaya yang berbeda antara budaya Jepang dan Indonesia serta rentan menimbulkan konflik. Untuk menemukan bahasa yang sarat unsur budaya dan rentan konflik, maka perlu dilakukan penelitian yang terkait masalah-masalah penggunaan bahasa yang timbul akibat perbedaan budaya. Pada penelitian ini, penulis berfokus pada konflik yang disebabkan oleh bahasa yang digunakan oleh lulusan bahasa Jepang ketika berkomunikasi dengan orang Jepang yang menimbulkan kesalahpahaman serta latar belakang nilai budaya yang menyebabkan kesalahpahaman tersebut.

Penelitian-penelitian sebelumnya sebagian besar dilakukan dengan responden orang asing yang bekerja di perusahaan Jepang di Jepang, dan masih sedikit yang melakukan penelitian dengan responden pekerja yang bekerja di luar negara asal perusahaan tersebut. Selain itu, penelitianpenelitian sebelumnya lebih banyak berfokus pada budaya dan bukan pada bahasa. Padahal konflik perbedaan budaya banyak disebabkan karena bahasa yang digunakan, karena bahasa tidak lepas dari budaya.

Tujuan penelitian ini adalah untuk 
mengetahui konflik-konflik yang disebabkan oleh bahasa yang menyebabkan kesalahpahaman akibat budaya dan latar belakang nilai budaya yang menyebabkan kesalahpahaman tersebut. Penelitian ini diharapkan dapat memberi masukan pada pembelajaran bahasa Jepang bisnis di masa datang di Indonesia, khususnya ketika membuat materi ajar. Fokus penelitian ini adalah konflik yang disebabkan oleh penggunaan bahasa yang sarat unsur budaya di dalam komunikasi interkultural. Adapun pertanyaan penelitian ini adalah sebagai berikut:

1. Bagaimanakah jenis konflik yang disebabkan oleh bahasa yang mengandung unsur budaya antara pekerja orang Indonesia dan pekerja asal Jepang di dunia bisnis?

2. Bagaimana latar belakang budaya dari penggunaan bahasa yang menyebabkan konflik antara pekerja orang Indonesia dan pekerja asal Jepang di dunia bisnis?

\section{METODE PENELITIAN}

Penelitian ini akan dilakukan menggunakan pendekatan kualitatif dengan metode penelitian studi kasus. Pengumpulan data menggunakan teknik wawancara mendalam (in-depth interview), di mana individu dipersilakan berbicara secara terbuka tentang suatu topik secara luas (Emzir, 2008). Responden penelitian ini adalah lulusan bahasa Jepang yang bekerja di perusahaan Jepang sebanyak empat orang (nama disamarkan). Responden yang dipilih adalah responden yang berkemampuan bahasa Jepang di atas level N3 JLPT, untuk menghindari pengaruh ketidakmampuan bahasa terhadap hasil penelitian. Data responden dapat dilihat pada Tabel 1. Data hasil wawancara kemudian dibuatkan transkrip dan dianalisis. Hasilnya dipaparkan dalam beberapa kategori untuk menjawab fokus dan subfokus pada penelitian ini.

Tabel 1. Data Responden

\begin{tabular}{cccccc}
\hline Nama & Usia & $\begin{array}{c}\text { Level } \\
\text { Kemampuan }\end{array}$ & Jenis Kelamin & Bidang perusahaan & Lama bekerja \\
\hline F & 25 & N2 & Pria & Animasi & 3 bulan \\
\hline T & 26 & N3 & Wanita & Property & 1 tahun 10 bulan \\
\hline O & 38 & N2 & Pria & Industri otomatif & 2 tahun \\
\hline Y & 28 & N1 & Wanita & Perbankan & 1 tahun 3 bulan \\
\hline \multicolumn{7}{r}{} & & \multicolumn{2}{c}{ (Sumber: data penelitian penulis) }
\end{tabular}

\section{HASIL DAN PEMBAHASAN}

\section{Jenis konflik yang disebabkan oleh bahasa}

Berdasarkan hasil dari wawancara dan analisis, maka konflik bahasa yang terkait budaya dapat dibagi menjadi dua, yaitu konflik yang disebabkan karena penggunaan bahasa verbal dan non-verbal.

\section{A. Konflik yang disebabkan oleh bahasa non-verbal}

Bahasa non-verbal yang ditemukan pada penelitian ini adalah gestur dan mimik. Gestur yang menjadi konflik dalam penelitian ini adalah gestur bersalaman. Di Indonesia, tidak semua orang berkenan 
bersalaman dengan bersentuhan tangan karena berkaitan dengan ajaran agama. Orang-orang tersebut akan mengalami ketidaknyamanan ketika diminta bersalaman terutama oleh orang yang berbeda jenis kelamin. Konflik yang disebabkan oleh gestur ini diungkapkan oleh Y, salah seorang responden penelitian ini.

"Kita kan ada yang Muslim ada yang tidak, mungkin ada yang Muslim gak ingin salaman, mungkin seperti itu, apalagi untuk “isei”（異 性） ('berbeda jenis kelamin pria dan wanita') gitu maksudnya gitu sih... Paling 'oh lu kok gamau salaman?' Gitu dianggap tidak sopan.”

Y yang merupakan seorang perempuan tidak mau bersalaman dengan tamu pria orang Jepang yang datang ke kantornya karena kepercayaan yang dianutnya. Hal ini menjadi masalah atau pertanyaan bagi atasannya yang merupakan orang Jepang.

Selain bersalaman, mimik juga menjadi masalah yang menyebabkan konflik. Orang Indonesia biasa menanggapi kritikan dengan cara tersenyum untuk membuat suasana rileks, akan tetapi hal tersebut tidak diterima oleh pekerja Jepang yang merupakan atasannya, karena di dalam budaya Jepang, seseorang harus menunjukkan muka serius dan menyesal ketika sedang diberikan kritik. Hal tersebut diungkapkan oleh responden $\mathrm{O}$.
"Kalau local person itu orang yang menanggapi sesuatu dengan senyuman gitu kan, semua kritik input dibiarkan dan dibalas dengan senyuman, lebih rileks gitu. Dan buat orang Jepang ketika dia memberitahu sesuatu, intense, ya aa lawannya itu kalau dalam posisi yang senyum aja bisa dianggap gak sopan."

Pada pernyataan di atas, $\mathrm{O}$ menggambarkan pengalamannya ketika dikritik oleh atasannya yang merupakan orang Jepang. $\mathrm{O}$ menanggapi kritikan atasannya dengan senyuman dan santai, karena hal itu baginya merupakan hal yang biasa. Akan tetapi, atasannya merasa hal itu tidak sopan. Bagi atasannya, ketika seseorang sedang dikritik, maka orang tersebut harus menunjukkan ekspresi serius mendengarkan dan mimik muka yang menunjukkan penyesalan.

Penelitian-penelitian sebelumnya kebanyakan berfokus pada bahasa verbal, akan tetapi belum terlihat penelitian yang berfokus pada bahasa non-verbal. Seperti yang diperlihatkan oleh pernyataanpernyataan dari kedua responden tersebut, bahasa non-verbal juga dipengaruhi oleh budaya dan dapat menimbulkan konflik. Untuk itu, perlu pengembangan penelitian mengenai bahasa non-verbal dan memasukan unsur bahasa non-verbal ke dalam buku teks bahasa Jepang bisnis.

\section{B. Konflik yang disebabkan oleh bahasa verbal}

Berdasarkan analisis data, ditemukan bahwa konflik yang disebabkan 
bahasa verbal dapat dibagi menjadi dua kategori, yaitu:

1. Konflik yang disebabkan karena penggunaan kata dalam bahasa Jepang

2. Konflik yang disebabkan karena penggunaan ungkapan atau ekspresi bahasa Jepang

\section{Konflik yang disebabkan karena penggunaan kata dalam bahasa Jepang}

Hasil analisis data menemukan bahwa konflik yang terjadi pada responden disebabkan karena penggunaan kata hubung “atode” (後で), aizuchi “soudesune” (そう ですね), dan kata “daijobu”(大丈夫). Konflik yang disebabkan oleh penggunaan kata hubung "atode", terlihat pada pernyataan $\mathrm{Y}$ berikut ini.

"Dia (orang Jepang) minta tolong 'atode yatte kudasai' (後で、やって ください) ('tolong kerjakan nanti'), dijawab 'oh hai wakarimasu' (はい、 わかります) ('ya, saya mengerti'), kemudian kemudian orang Jepangnya pergi. Terus datang lagi kayaknya engga lama sih mungkin sekitar 15 menit kemudian gitu. Datang trus tanya 'ininya bagaimana? sudah dikirim belum? e-mailnya yang tadi'.,

Situasi dalam pernyataan $\mathrm{Y}$ ini adalah Y dimintai tolong untuk melakukan suatu pekerjaan, yaitu membuat dan mengirim email. Kalimat perintah yang digunakan atasan $\mathrm{Y}$ yang merupakan orang Jepang adalah "atode yatte kudasai" ('Tolong kerjakan nanti'). Ketika menerima perintah ini, Y menjawab dengan kalimat "oh hai, wakarimasu" ('ya, saya mengerti') karena ia merasa sudah mengerti perintah atasannya. Hanya saja dalam pemahaman Y untuk waktu pekerjaannya adalah "nanti" atau tidak harus sesegera mungkin. Pemahaman ini mengacu pada adverbia yang digunakan oleh atasannya yaitu "atode". Sekitar 15 menit setelah memberi perintah, atasan tersebut menghampiri $\mathrm{Y}$ dan bertanya mengenai email yang diminta dibuatkan dan dikirimkan sebelumnya. Namun Y belum mengerjakannya. Atasan Y merasa kecewa atas kejadian tersebut karena baginya adverbia "atode" bermakna sesegera mungkin.

Kesalahpahaman antara $\mathrm{Y}$ dan atasannya terjadi karena perbedaan pemahaman mengenai makna adverbial "atode". Bagi orang Indonesia, kata "atode" tidak mengandung arti durasi waktu 'sesegera mungkin, melainkan menunjukkan durasi waktu yang agak panjang. Kesalahpahaman ini terjadi karena budaya yang terkait dengan waktu. Orang Jepang sangat menghargai waktu, dan berusaha memanfaatkan waktu sebaik mungkin. Rasa (sense) terhadap durasi waktu antara orang Indonesia dan orang Jepang berbeda. Kata "atode" dalam bahasa Indonesia bermakna 'nanti'. Kata "nanti" dalam KBBI adalah 'waktu yang tidak lama dari sekarang' sedangkan dalam kamus weblio.jp berarti "現在ではない、以後いく らか経過した時点を指す表現 Genzai dewanai, ikou ikuraka keikashita jiten o arawasu hyougen" 'Ekspresi yang menggambarkan bukan saat ini, melainkan waktu beberapa saat kemudian'. Berdasarkan kedua kamus tersebut, kata 
"nanti" dan "atode" memiliki makna yang mirip. Akan tetapi, yang menjadi masalah adalah rasa terhadap durasi waktu orang Indonesia dan orang Jepang pada kata ini. Rasa terhadap durasi waktu kata "atode" orang Jepang lebih singkat dari orang Indonesia.

Kata selanjutnya yang muncul di data dan menyebabkan konflik adalah kata jenis aizuchi (tanggapan atau sisipan yang dilakukan di tengah pembicaraan) “soudesune” (そうですね). Aizuchi ini mempunyai beberapa fungsi, yaitu sebagai tanggapan ketika pembicara setuju dengan pernyataan lawan bicara, dan ekspresi ketika pembicara sedang berpikir. Konflik akibat kata "soudesune" ini terlihat pada pernyataan $\mathrm{Y}$.

"JJam dua nanti jadi gak kenshuu-nya ('pelatihan'), jadi gak training-nya kayak gitu?' (orang Jepang hanya mengatakan) 'ah sou desune', gitu aja. Trus abis itu dia biasanya sibuk."

Situasi dalam pernyataan di atas adalah Y bertanya kepada atasannya yang merupakan orang Jepang, tentang jadi atau tidaknya pelatihan yang akan dilakukan. Mendengar hal ini atasannya hanya menjawab dengan aizuchi "ah sou desune", tanpa berkata apa-apa lagi. Sikap atasan tersebut membuat $\mathrm{Y}$ bingung. $\mathrm{Y}$ tidak paham apakah atasan orang Jepang tersebut setuju tentang pelaksanaan pelatihan atau masih dipikirkan terlebih dulu.

Budaya Jepang merupakan budaya konteks tinggi, artinya sebagian informasi tidak didapat dari kata-kata, melainkan dari konteks yang meliputinya (Hall, 1988). Yang dimaksud dengan konteks di sini adalah situasi yang merupakan latar belakang dari suatu kejadian atau tindakan. Indonesia juga termasuk budaya konteks tinggi, akan tetapi lebih rendah daripada budaya Jepang. Konflik yang terjadi pada kasus aizuchi ini disebabkan karena perbedaaan budaya yang terkait dengan konteks ini. Y hanya melihat dari makna aizuchi yang dilontarkan oleh atasannya yang kebetulan mempunyai dua makna atau ambigu, akan tetapi tidak melihat konteks. Konteks di sini bisa berupa gerak tubuh, raut muka, ataupun situasi lainnya. Apabila Y melihat konteks, maka kemungkinan besar dapat menentukan makna mana yang digunakan atasannya pada aizuchi "ah sou desune" yang dilontarkannya.

Selain itu, kata “daijobu” (大丈夫) juga menjadi kata yang menimbulkan kesalahpahaman, seperti dalam pernyataan $\mathrm{F}$ berikut ini.

"Ummm, kadang... Oh kadang misalnya kalo sepengalaman saya ada. Ada scene/adegan yang dibilang umm saya bilang ini harusnya dikerjakannya gimana? Karena harus ada materi yang ditambah atau engga? Nah trus dia (atasan orang Jepang) bilang, 'daijoubu desu' ('tidak apaapa'). Nah, “daijoubu” itu saya malah ngiranya gak apa-apa atau diabaikan saja.

Situasi di atas adalah ketika F menanyakan pekerjaan menggambar bagian dari animasi yang harus dikerjakannya. F menanyakan 
apakah perlu ditambahkan gambar atau tidak. Pada saat itu atasan orang Jepangnya mengatakan "daijoubu desu" ('tidak apaapa')." Ketika mendengar kata “daijoubu”, F berpikir bahwa tidak apa-apa atau tidak perlu dikerjakan lagi semuanya. Akan tetapi maksud dari atasannya adalah tetap kerjakan sesuai dengan materi yang diminta di gambar saja.

Kata "daijoubu" juga merupakan kata yang bermakna ganda atau ambigu yang sering membuat bingung penutur asing bahasa Jepang. Konflik yang terjadi pada kata "daijoubu" ini, sama dengan konflik yang terjadi pada aizuchi "sou desune", yaitu karena perbedaan budaya konteks tinggi dan rendah. Untuk memahami makna kalimat "daijoubu desu", maka $\mathrm{F}$ perlu membaca konteks ketika atasannya mengucapkan kalimat tersebut.

\section{Konflik yang disebabkan karena penggunaan ungkapan atau ekspresi dalam bahasa Jepang}

Konflik berikutnya adalah konflik yang disebabkan karena penggunaan ungkapan atau ekspresi dalam bahasa Jepang. Terdapat dua ekspresi yang ditemukan dalam data penelitian, yaitu ekspresi meminta tolong dan ekspresi memerintah.

Ekspresi meminta tolong di sini adalah "otesudesuga, sumimasen" (お手数 ですが、すみません) ('mohon maaf merepotkan'). Konflik ini ditemukan pada data $\mathrm{T}$ sebagaimana terlihat pada pernyataan berikut.

\begin{abstract}
"Kalo dari beliau sendiri, aa kalo untuk secara ngomong ngobrol biasa gitu yaa, tapi ya kalo udah misalnya nyuruh ni Tiana 'nantoka kudasai' (な んとかください) ('bagaimapun tolong!') Nah, pasti terakhirnya beliau bilang 'otesudesuga, sumimasen' ('mohon maaf merepotkan di tengah kesibukan'), gitu."
\end{abstract}

Atasan $\mathrm{T}$ sering memberikan tugas yang sangat banyak, sementara masih banyak tugas lain yang belum diselesaikan oleh T. Pada saat itu $\mathrm{T}$ merasa tidak nyaman, tetapi tidak dapat menolak karena atasan orang Jepang tersebut mengatakan "otesudesuga, sumimasen" ("mahon maaf merepotkan di tengah kesibukan'). Ekspresi ini menjadi tekanan pada $\mathrm{T}$ untuk menolak perintah atasannya, atau untuk mengatakan bahwa banyak pekerjaan lain belum selesai.

Konflik yang terjadi pada $\mathrm{T}$ dan atasannya adalah karena budaya kerja yang terkait dengan budaya kerja yang disebut horenso yaitu singkatan dari hokoku ('lapor'), renraku ('hubungi'), dan soudan' ('diskusi'). Segala sesuatu harus dilaporkan, selalu menghubungi pihak terkait, dan selalu berdiskusi dengan pihak-pihak yang terkait dengan pekerjaan yang dilakukan.

Ekspresi selanjutnya adalah ekspresi perintah "nani ka attara renraku shitene" (何かあったら、連絡してね) ('kalau ada apa-apa tolong kasih tahu'). Kondisi ketika terjadi konflik ini adalah kondisi dimana perusahaan $\mathrm{T}$ sedang menerima tamu. $\mathrm{T}$ diperintahkan untuk membeli oleh-oleh 
coklat dengan merek tertantu dan di ujung perintah tersebut terdapat ekspresi perintah "nani ka attara renraku shitene" ("kalau ada apa-apa tolong kasih tahu'). T memaknai ekpresi ini bahwa ia harus selalu melaporkan atau bertanya apapun yang dianggapnya perlu ditanyakan sampai sedetail-detailnya. Setiba di toko, T tidak menemukan merek coklat yang diminta. $\mathrm{T}$ segera menghubungi atasannya untuk menanyakan apakah bisa diganti dengan merk lain. Akan tetapi, di luar dugaan dia mendapat teguran karena atasannya berpendapat bahwa $\mathrm{T}$ harus bisa memutuskan sendiri dalam kondisi itu.

Ekspresi "nani ka attara renraku shitene" ("kalau ada apa-apa tolong kasih tahu'), juga terkait erat dengan budaya kerja horenso. $\mathrm{T}$ merasa perlu melaporkan apapun yang dia lakukan, hadapi, atau putuskan kepada atasannya.

\section{Latar Belakang Budaya yang Menyebabkan Konflik}

Latar belakang budaya yang menyebabkan konflik dapat dibagi menjadi lima kategori, yaitu:

1. Pandangan tentang sentuhan fisik

2. Sikap ketika menerima kritik

3. Rasa (sense) terhadap durasi waktu

4. Kata bermakna ambigu dan kaitannya dengan budaya konteks tinggi dan rendah

5. Budaya kerja

Sikap menerima kritik antara orang Indonesia dan Jepang yang berbeda membuat kemungkinan terjadinya konflik semakin besar. Orang Indonesia menerima kritik dengan santai, bahkan tersenyum, sementara orang Jepang menerima kritik dengan mimik serius dan menyesal, sebagaimana terlihat pada konflik akibat bahasa non-verbal di atas.

Adapun konflik yang terkait dengan sentuhan fisik, pada dasarnya orang Jepang pun tidak terbiasa dengan sentuhan fisik. Akan tetapi, akibat adanya anggapan bahwa semua orang Indonesia bersalaman ketika pertama kali berjumpa, maka banyak yang berusaha mengikuti budaya tersebut untuk menghormati budaya Indonesia. Namun pada kenyataannya, tidak semua orang Indonesia bersedia melakukan salaman, terutama dengan jenis kelamin yang berbeda. Hal ini terkait dengan ajaran agama yang dipercayai individu tersebut. Ketidakpahaman orang Jepang akan hal ini sering menimbulkan konflik.

Konflik yang dipicu oleh adverbia "atode" ('nanti') disebabkan karena perbedaan rasa akan waktu (sense of time) yang terkait dengan kata tersebut. Bagi orang Indonesia kata "nanti" bisa mengandung arti 'jeda/durasi waktu agak panjang', sementara bagi orang Jepang merupakan 'jeda waktu yang pendek'.

Budaya Jepang adalah budaya konteks tinggi, sedangkan budaya Indonesia adalah budaya konteks yang lebih rendah dibandingkan budaya Jepang. Bahasa Jepang memiliki banyak sekali kata yang bermakna ambigu atau ganda. Untuk dapat memaknai dengan tepat kata-kata atau ekspresi yang bermakna ambigu, maka penutur asing berbahasa Jepang harus melihat informasi di luar kata-kata atau ekspresi tersebut, yaitu konteks ketika katakata atau ekspresi tersebut digunakan. 
Dalam data ditemukan dua kata yang bermakna ambigu, yaitu jenis kata "sou desune" dan "daijoubu". "Sou desune" mempunyai dua pengertian, yaitu 1) 'menyetujui pernyataan lawan bicara', dan 2) dipakai ketika berpikir. Kata "daijoubu" juga memiliki dua makna, yaitu 1) 'ya' atau 2) 'tidak'. Contohnya, ketika menjawab tawaran minum, kata "daijoubu" dapat berarti 'tidak mau'. Kata-kata ambigu ini hanya bisa dipahami melalui konteks.

Budaya kerja yang berbeda juga merupakan faktor penyebab konflik. Hal ini terlihat dari ekspresi "otesudesuga, sumimasen" ('mohon maaf merepotkan'). Orang Jepang dikenal sebagai pekerja keras dan selalu terencana. Mereka juga mempunyai budaya kerja yang disebut horenso (melaporkan, menghubungi, dan berdiskusi). Segala sesuatu harus dilaporkan, selalu menghubungi pihak terkait, dan selalu berdiskusi dengan pihakpihak yang terkait dengan pekerjaan yang dilakukan. $\mathrm{T}$ dapat melakukan kompromi kepada atasanya dengan melaporkan kondisi yang sebenarnya dan mendiskusikan dengan atasannya. Akan tetapi, karena $\mathrm{T}$ memaknai ungakapan/ ekspresi “otesudesuga, sumimasen" sebagai ekpresi yang tidak bisa ditolak, maka terjadi ketidaknyamanan di diri $\mathrm{T}$ ketika melakukan tugas yang diberikan. Ekspresi "nani ka attara renraku shitene" ("kalau ada apa-apa tolong kasih tahu'), juga terkait erat dengan budaya kerja horenso. Oleh karena itu, $\mathrm{T}$ merasa perlu melaporkan apapun yang dia lakukan, hadapi, atau putuskan dengan atasannya. Padahal ada beberapa hal, khususnya yang tidak terlalu menyangkut untung-rugi perusahaan, yang bisa diputuskan sendiri.

Dari sini terlihat jelas bahwa bahasa dan budaya terkait erat dan tak bisa dipisahkan. Ada beberapa unsur bahasa yang hubungannya sangat erat, sehingga apabila pihak-pihak yang terlibat berada di dalam situasi interkultural dan tidak mengerti hubungan bahasa dan budaya tersebut, maka situasi ini rentan menimbulkan konflik.

\section{KESIMPULAN}

Dari hasil analisis di atas, maka dapat disimpulkan bahwa konflik antara pekerja Indonesia dan Jepang dapat disebabkan oleh penggunaan bahasa, baik verbal maupun non-verbal. Konflik ini juga tak luput dari unsur perbedaan budaya yang berada di balik bahasa (kata, ungkapan/ ekspresi, dan sebagainya). Seperti yang telah disebutkan pada bagian pendahuluan, bahasa tidak bisa dipisahkan dari budaya.

Pembelajaran bahasa Jepang bisnis yang erat kaitannya dengan perbedaan budaya ini sangat perlu dilakukan di dunia pendidikan untuk mengurangi terjadinya konflik di lingkungan kerja. Akan tetapi, buku-buku pelajaran bahasa Jepang bisnis yang memasukkan unsur budaya masih sangat sedikit, seperti yang terlihat pada hasil penelitian Nishitani (2014) dan Kin (2009).

Unsur budaya di sini sebaiknya spesifik pada unsur budaya yang terkait dengan budaya pembelajar, karena budaya masing-masing berbeda. Penelitian kali ini masih dalam skala kecil. Selanjutnya, perlu dilakukan penelitian dalam skala besar 
untuk mengumpulkan unsur bahasa lain yang rentan menimbulkan konflik. Penelitian ini juga merupakan penelitian awal untuk melihat permasalahan bahasa dalam dunia korporasi dari segi sosiopragmatik.

Hasil penelitian ini diharapkan dapat memberikan kontribusi pada pembuatan buku ajar bahasa Jepang bisnis yang tidak hanya memasukkan unsur bahasa, namun juga unsur budaya untuk mengatasi permasalahan yang terkait dengan kedua unsur tersebut dalam dunia bisnis.

\section{DAFTAR PUSTAKA}

Emzir. (2008). Metodologi Penelitian Pendidikan Kuantitif dan Kualitatif. Raja Grafindo Persada.

Hall, E. T. (1988). Context and Meaning. In L. A. Samovar \& R. E. Porter (Eds.), Intercultural Communication: A Reader (p. La). Wadsworth, Inc.

Harzing, A. W., Köster, K., \& Magner, U. (2011). Babel in business: The language barrier and its solutions in the HQ- subsidiary relationship. Journal of World Business, 46(3), 279-287. https://doi.org/10.1016/j.jwb.2010.07.00 $\underline{5}$

Kin, S. (2009). Business Japanese Content in Text Books. Intercultural Studies Review, 32, 70-87.

Nishitani, M. (2014). Development of Japanese business communication materials. Hitotsubashi University International Center Departmental Bulletin Paper, 5, 105-112.

Nishitani, M. (2016). Failure and Anxiety in Business Communication: Comparison of Japanese Employees and Vietnamese Employees of Japanese Companies Located in Vietnam. Journal of Global Education, 7, 3-14.

Peltokorpi, V. (2010). Intercultural communication in foreign subsidiaries : The influence of expatriates ' language and cultural competencies. Scandinavian Journal of Management, 26(2), 176-188. https://doi.org/10.1016/j.scaman.2010.0 $\underline{2.003}$ 